\title{
Combining laser-Doppler flowmetry and photoplethysmography to explore in vivo vascular physiology
}

\author{
Combinando a fluxometria por laser-Doppler e a fotopletismografia na exploração da \\ fisiologia vascular in vivo
}

\author{
Henrique Silva ${ }^{1,2}$, Clemente Rocha ${ }^{1}$, L Monteiro Rodrigues ${ }^{1,2}$ \\ ${ }^{1}$ CBIOS - Universidade Lusófona's Research Center for Biosciences and Health Technologies, Lisboa, Portugal \\ ${ }^{2}$ Pharmacol. Sc Depart — Universidade de Lisboa, Faculty of Pharmacy, Lisboa, Portugal \\ Email: henrique.silva@ulusofona.pt
}

\begin{abstract}
Laser Doppler flowmetry (LDF) and photoplethysmography (PPG) are two well-known optical techniques, allowing sensible real-time in vivo recording of blood flow. Only a few studies have used simultaneous perfusion recordings with both techniques, meaning that not much is known regarding the utility of their combined use. Our aim was to assess the vascular response of healthy individuals to a challenge maneuver with both techniques. Twelve subjects (both sexes, $26.0 \pm 5.0$ years old), were selected after informed written consent. The chosen maneuver was the leg pending maneuver, with LDF and PPG being assessed in both feet, and with transcutaneous O2 (tc) pressure obtained by gasimetry, and pulse rate (PR) calculated from the PPG signal, being also registered. The Wilcoxon signed-rank test was used for phase comparisons $(\mathrm{p}<0.05)$. Leg pending significantly reduced perfusion on both feet, although more clearly on the pending foot. The venoarterial reflex explains this vasoconstriction while, in the unmoved foot, a centrally-mediated reflex might be involved. tcpO2 increased significantly during leg lowering, suggesting that the heat from the probe cancelled the venoarteriolar reflex (VAR) on the measurement region. No changes were seen in HR. This study seems to confirm that the combined use of LDF and PPG might help to look deeper into peripheral microcirculation mechanisms.
\end{abstract}

Keywords: laser Doppler flowmetry; photoplethysmography; microcirculation; postural change; venoarteriolar reflex

\section{Resumo}

A fluxometria por laser Doppler (FLD) e a fotopletismografia (FPG) são duas técnicas óticas bem conhecidas, que possibilitam a gravação em tempo real in vivo de leituras sensíveis do fluxo sanguíneo. Apenas alguns estudos utilizaram recolha de dados de perfusão com as duas técnicas em simultâneo, significando que pouco se conhece sobre a utilidade deste uso combinado. O nosso objetivo foi o de avaliar a resposta vascular em indivíduos saudáveis para uma manobra de provocação com ambas as técnicas. Doze voluntários (ambos os sexos, $26.0 \pm$ 5.0 anos), foram selecionados após obtenção de consentimento informado. A manobra escolhida foi a manobra de pendência da perna, com a FLD e FPG registadas em ambos os pés, registando-se também a pressão transcutânea (tc) de $\mathrm{O} 2$ obtida por gasimetria e a frequência de pulso (FP) calculada a partir do sinal FPG. O teste de Wilcoxon para amostras emparelhadas foi usado para comparação das diferentes fases $(\mathrm{p}<0.05)$. A perna pendente reduziu de forma significativa a perfusão em ambos os pés, embora de modo mais significativa no pé pendente. O reflexo venoarteriolar (RVA) explica esta vasoconstrição, enquanto que no pé imóvel, um reflexo medular poderá estar envolvido. A tcpO2 aumentou significativamente durante o abaixamento da perna, o que sugere que o aquecimento da sonda anulou o RVA na zona de medição. Não se verificaram alterações em termos de FP. Este estudo parece confirmar que o uso combinado de FLD e FPG pode ajudar a olhar com maior profundidade para a fisiologia da microcirculação periférica.

Palavras-chave: fluxometria por laser Doppler; fotopletismografia; microcirculação; alteração postural; reflexo venoarteriolar 


\section{Introduction}

Skin is a recognized surrogate for the study of microcirculation physiology and pathophysiology ${ }^{[1]}$. It provides accessible vascular networks and the acquisition of several biological signals by noninvasive techniques ${ }^{[2-4]}$. Laser Doppler flowmetry (LDF) is the most wellknown technique used with that purpose, although the classical photoplethysmography is recently being revisited ${ }^{[7,8]}$. Both are optical techniques, allowing sensible, real-time recording of blood flow. Nevertheless, several variability sources (biological and artefactual) affect blood flow analysis, no matter the method used. For that reason, vascular function is often explored by provocation tests, involving maneuvers that change the normal perfusion conditions, triggering regulatory mechanisms. All the responses are recorded and quantified while the discriminative power of the technique is reinforced ${ }^{[2,3,5]}$. Some provocation tests induce systemic/regional changes in perfusion, such as the limb occlusion (post occlusive reactive hyperaemia) and the limb postural changes ${ }^{[4,5]}$, while others only act at local level (topical drug challenge) ${ }^{[6]}$.

Experience about the simultaneous use of both LDF and PPG techniques is scarce, so that the usefulness of this combined assessment is not established. For that reason, we decided to characterize that association in the present study.

\section{Materials and Methods}

Twelve subjects $(26.0 \pm 5.0$ years old $)$, both genders, participated in this study after selection, giving their informed written consent. Subjects were healthy, not under any kind of medication, and instructed not to consume caffeinated or alcoholic beverages 24 hours prior to the beginning of the study. All experiments were performed in conformity with the declaration of Helsinki and its subsequent amendments ${ }^{[9]}$. Measurements were taken in temperature and humidity controlled conditions $\left(22 \pm 1^{\circ} \mathrm{C}, 40-60 \%\right)$. Subjects were allowed to acclimatize to the room conditions, lying in the supine position for 20 minutes prior to the beginning of the recordings. The protocol consisted of three phases 10 minute stabilization period, with the subject lying supine (phase I); 10 minute provocation period, with one randomly chosen leg pending $50 \mathrm{~cm}$ below heart level for 10 minutes while the contralateral remained unmoved (phase II), as illustrated in Figure 1; and 10

\section{Introdução}

A pele é reconhecidamente um bom modelo para o estudo da fisiologia e da fisiopatologia da microcirculação ${ }^{[1]}$. Proporciona redes vasculares acessíveis e a fácil aquisição de vários sinais biológicos através de técnicas não invasivas ${ }^{[2-4]}$. A fluxometria por laser Doppler (FLD) é a técnica mais bem conhecida usada com este propósito, apesar da fotopletismografia clássica ter vindo a ser recentemente revisitada ${ }^{[7,8]}$. Ambas são técnicas óticas, permitindo o registo detalhado do fluxo sanguíneo em tempo real. No entanto, diversas fontes de variabilidade (biológica, artefactos) afetam a análise do fluxo sanguíneo independentemente do método de análise usado. Por este motivo, a exploração da função vascular é muitas vezes efetuada através de testes de provocação, envolvendo manobras que, accionando mecanismos de regulação, alteram as condições normais de perfusão. Todas as respostas são gravadas e quantificadas enquanto o poder discriminativo das técnicas é reforçado ${ }^{[2,3,5]}$. Alguns testes de provocação induzem alterações na perfusão sistémica/regional, tais como a oclusão do membro (hiperemia reativa pós oclusiva) e a alteração postural dos membros ${ }^{[4,5]}$, enquanto que outras apenas atuam a um nível local (fármacos de aplicação tópica) ${ }^{[6]}$.

A utilização simultânea das técnicas de FLD e FPG raramente é encontrada na literaturas, de modo que a utilidade desta avaliação combinada não é conhecida. Por este motivo, decidimos caracterizar esta associação no presente estudo.

\section{Materiais e Métodos}

Doze voluntários (26.0 \pm 5.0 anos $)$, de ambos os sexos, participaram neste estudo após terem sido seleccionados, dando o seu consentimento informado por escrito. Os voluntários eram saudáveis, não sujeitos a nenhuma medicação e, instruídos para não consumir cafeína e bebidas alcoólicas num período não inferior a 24 horas antes do início do estudo. Todas as experiências foram realizadas em conformidade com a declaração de Helsínquia, assim como as suas respetivas emendas ${ }^{[9]}$. As medições foram realizadas num laboratório com temperatura e humidade controladas $\left(22 \pm 1{ }^{\circ} \mathrm{C}, 40-60 \%\right)$. Os voluntários foram aclimatizados às condições da sala na posição de supinação durante 20 min antes do início das medições. O protocolo consistiu em três fases - 10 min de período de estabilização, com o voluntário deitado na posição em supinação (fase I); 10 min de provocação, consistindo em colocar uma das pernas, escolhida de forma aleatória, pendente, $50 \mathrm{~cm}$ abaixo do nível 


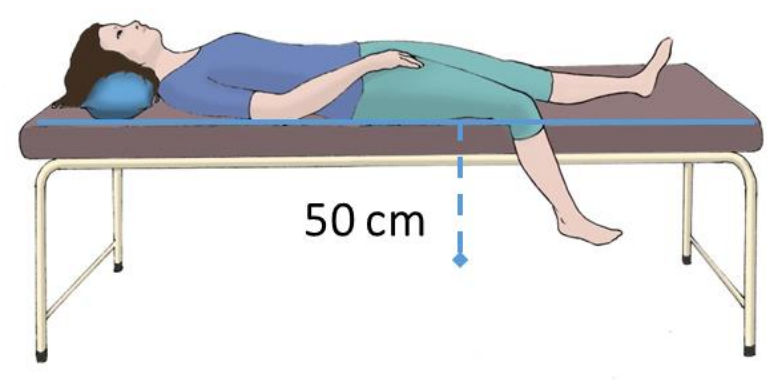

Figure 1/ Figura 1 - Illustrative scheme of the posture adopted by the subjects during the provocation phase of the protocol Esquema ilustrativo da postura adotada pelos voluntários durante a fase de provocação do protocolo

minute recovery period, returning to the initial position (phase III). Measured variables included local blood flow measured by LDF (PF 5010, Perimed, Sweden), and reflection PPG using a Bitalino ${ }^{\mathrm{TM}}$ microprocessor board (PLUX Biosystems, Portugal) and transcutaneous (tc) $\mathrm{pO}_{2}$ by gasimetry (PF 5040, Perimed, Sweden). Blood flow was measured on both feet, with the LDF probes attached to the second toes while PPG probes were placed in the first toes with double-sided adhesive strips. A third PPG sensor was clipped to a randomly chosen ear lobe with a metal clip. The tcpO $\mathrm{O}_{2}$ sensor was attached to the dorsum of the pending foot only, between the projection of the first two toes. The mean values of the last five minutes of each phase were used for analysis in each variable. Pulse rate (PR), which is synchronous with the heart rate, was calculated from the earlobe PPG signal for each phase as $P R=60 /$ mean peak interval. The Wilcoxon signed-rank test for related samples was used for phase comparison, adopting of a confidence interval of 95\% (SPSS 21, Microsoft).

\section{Results and Discussion}

PPG and LDF are optical techniques that assess blood flow through different principles. PPG quantifies the amount of visible light reflected by blood vessels, mainly arteries but also microcirculatory vessels, in do coração durante 10 min, mantendo a perna contra lateral na mesma posição(fase II), conforme ilustrado na figura 1; e 10 min de recuperação, retornando à posição inicial (fase III). As variáveis medidas incluíram o fluxo sanguíneo por FLD (PF 5010, Perimed, Suécia), e FPG usando a placa microprocessadora Bitalino ${ }^{\mathrm{TM}}$ (PLUX Biosystems, Portugal) e $\mathrm{pO}_{2}$ transcutânea (tc) por gasimetria (PF 5040, Perimed, Suécia). O fluxo sanguíneo foi medido em ambos os pés, com as sondas FLD aplicadas no segundo dedo do pé, enquanto as sondas FPG foram aplicadas no primeiro dedo com tiras de fita adesiva de dupla face. Um terceiro sensor de FPG foi colocado com um clip metálico no lóbulo de uma orelha escolhida de forma aleatória . O sensor de tcpO foi fixado apenas no dorso do pé pendente, entre a projeção dos dois primeiros dedos. Foram utilizados os valores de media dos últimos 5 minutos de cada fase para análise em cada variável. A frequência de pulso (FP), que é síncrona com a frequência cardíaca, foi calculada a partir do sinal de FPG do lóbulo da orelha para cada fase com $\mathrm{FP}=60$ /intervalo médio de picos. $\mathrm{Na}$ comparação das diferentes fases, foi utilizado o teste de Wilcoxon para amostras emparelhadas, tendo-se adotado um intervalo de confiança de 95\% (SPSS 21, Microsoft).

\section{Resultados e Discussão}

A FPG e a FLD são técnicas óticas que avaliam o fluxo sanguíneo através de diferentes princípios. A FPG quantifica a quantidade de luz visível refletida pelos vasos sanguíneos, principalmente pelas artérias, mas 

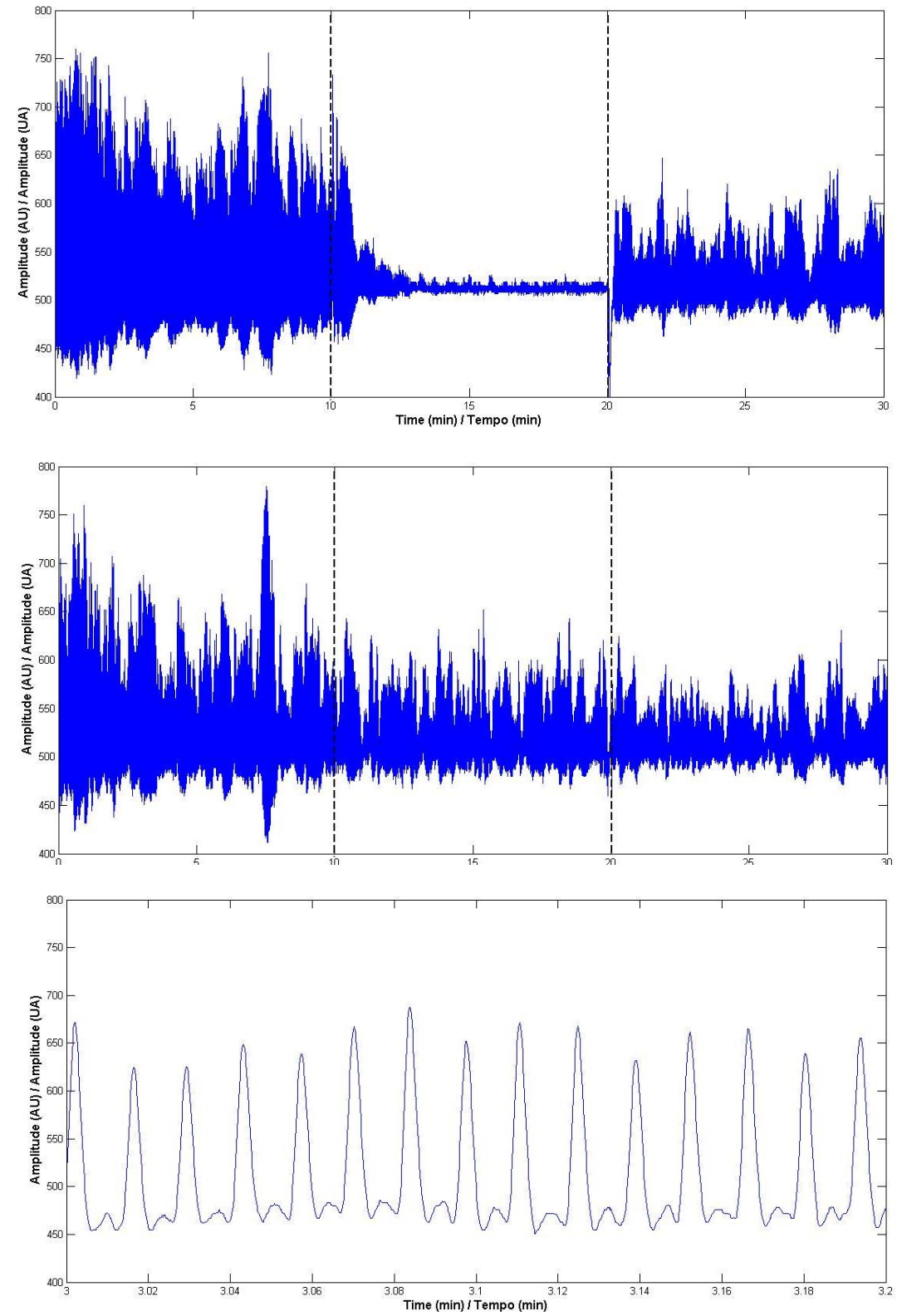

Figure 2/ Figura 2 - PPG signal of one representative subject during the $30 \mathrm{~min}$ protocol for the moved (top) and the unmoved foot (middle). Recording of the PPG signal in the unmoved foot during a 12 second time window (bottom). Dashed lines indicate the transition between phases. Sinal de FPG de um voluntário representativo durante o protocolo de 30 min para o pé não movido (em cima) e para o pé movido (em baixo). Registo do sinal de FPG no pé não movido durante uma janela tempoeral de 12 segundos. As linhas tracejadas indicam a transição entre fases.

proportion to the blood volume perfusing the vessels immediately after a given heartbeat ${ }^{[10]}$. This explains the morphology of the signal shown in Figure 2. It allows a direct calculation of heart rate and an indirect, albeit reliable, calculation of respiratory rate ${ }^{[11]}$. It has been used for the detection of cardiac arrhythmias and for assessing the influence of the respiration on the cardiovascular system ${ }^{[12,13]}$. However, the quantitative characterization of PPG still needs to be done, and this também por vasos microcirculatórios, em proporção ao volume de sangue que perfune os vasos imediatamenteapós um dado batimento cardíaco ${ }^{[10]}$. Isto explica a morfologia do sinal apresentado na figura 2. Esta situação permite um cálculo direto da frequência cardíaca, e um cálculo indireto, no entanto fiável, da frequência respiratória ${ }^{[1]}$. Tem sido usada para a deteção de arritmia, e para a avaliação da influência da respiração no sistema cardiovascular ${ }^{[12,13]}$. No entanto a caracte- 
is a serious limitation for the method. In contrast, LDF quantitatively describes (although by arbitrary units), the velocity of moving erythrocytes in microvascular beds by the frequency change suffered by a laser beam that impinges upon them. Multiplying this velocity by a stochastic estimation of the number of cells, a value of 'flow' is estimated ${ }^{[14]}$. Due to its higher sensitivity, in comparison to PPG, LDF is more suitable for the assessment of the small oscillations found in the microvascular flow and, consequently, for the study of its local regulatory mechanisms ${ }^{[15]}$. Figures 2 and 3 show the amplitude changes of the LDF and PPG signals in both feet during the protocol execution.

Table 1 summarises mean and standard deviation values for each variable, the percent change of each variable from phase I to phase II, and the p values of the statistical comparisons performed. Upon lowering the rização quantitativa do FPG continua a ser necessária, sendo esta uma limitação séria a uma maior utilização do método. Em contraste, a FLD descreve quantitativamente (apesar de por meio de unidades arbitrárias), a velocidade de movimentação dos eritrócitos nos vasos microcirculatórios, pela alteração de frequência sofrida por um feixe de radiação laser que sobre aqueles incide. Multiplicando esta velocidade por uma estimativa estocástica do número de células, é estimado um "fluxo" [14]. Devido à sua maior sensibilidade comparativamente ao FPG, o FLD é mais adequado para a avaliação de oscilações mais pequenas encontradas no fluxo microvascular e consequentemente, para o estudo dos seus mecanismos regulatórios locais ${ }^{[15]}$. As Figuras 2 e 3 mostram as mudanças de amplitude dos sinais de FLD e FPG em ambos os pés durante o protocolo.

A Tabela 1 resume os valores de média e desvio padrão
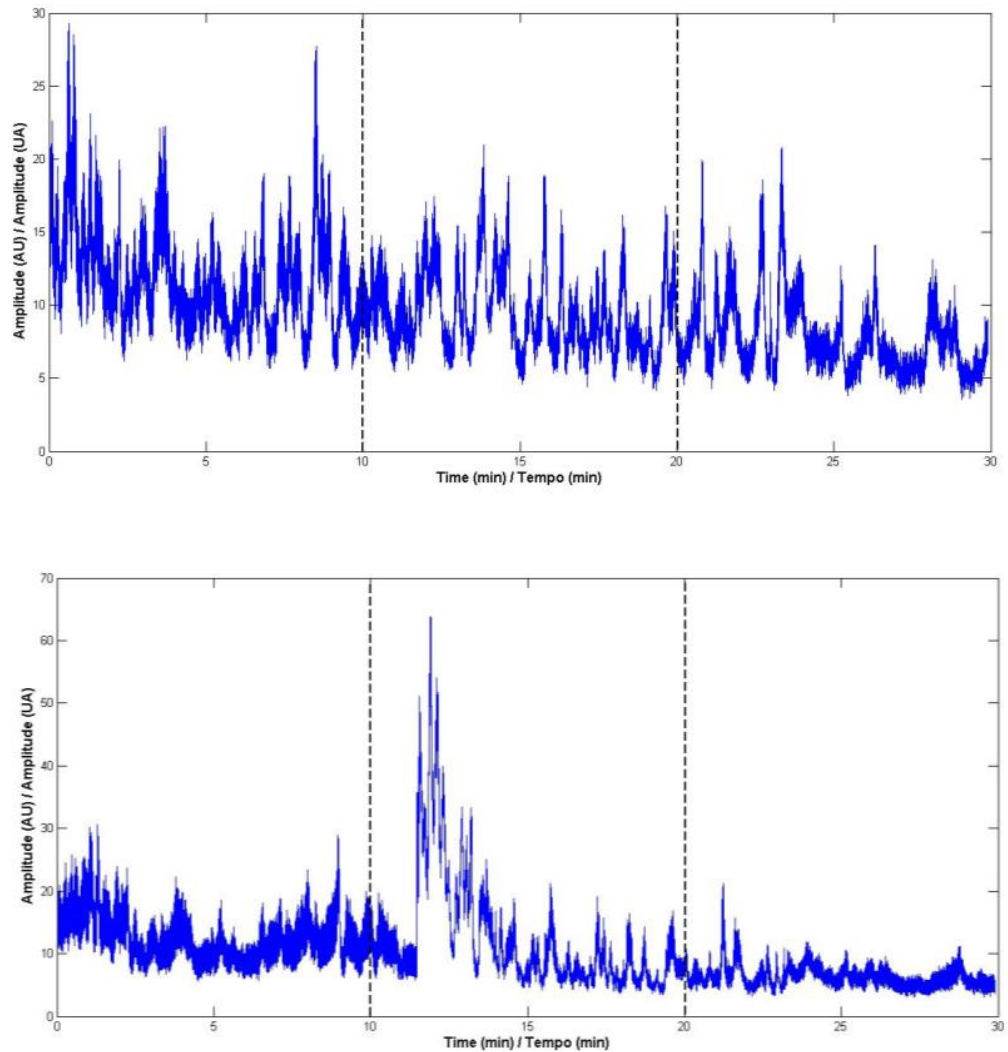

Figure 3/ Figura 3 - LDF signal of one representative subject during the $30 \mathrm{~min}$ protocol for the unmoved (top) and moved foot (bottom). Dashed lines indicate the transition between phases.

Sinal de FLD de um voluntário representativo durante o protocolo de 30 min para o pé não movido (em cima) e para o pé movido (em baixo). As linhas tracejadas indicam a transição entre fases. 
foot below heart level, a significant perfusion reduction occurred, as noted by the significant decrease in the amplitude of LDF and PPG signals between phases I and II $(-47.0 \%, \mathrm{p}=0.002$ and $-84.0 \%, \mathrm{p}=0.010$, respectively). This perfusion drop is attributable to the venoarteriolar reflex (VAR), which consists in an arteriolar constriction in response to an increase in venous pressure ${ }^{[16]}$. Upon lowering the foot, the blood accumulated on the extremity due to gravity, increasing the pressure in those vascular territories. The increase in venous transmural pressure is thought to elicit a local arteriolar constriction by a non-adrenergic neural-mediated reflex, reducing microcirculatory blood flow ${ }^{[17]}$. Furthermore, it is also believed that the increase in transmural arterial pressure induces a myogenic tone increase, also contributing to the perfusion reduction ${ }^{[18]}$. The sympathetic nervous system also seems to influence VAR, in particular in the orthostatic position, by baroreceptor-mediated activation ${ }^{[19]}$. In the present study subjects remained supine, thus avoiding baroreceptor mediated-changes (HR did not change significantly during postural changes, corroborating our analysis). Despite the perfusion reduction in this toe, a significant increase in $\mathrm{tcpO}_{2}$ was noted para cada uma das variáveis, a variação percentual de cada variável da fase I para a fase II e os valores de p da comparação estatística efetuada. Após o abaixamento do pé para uma posição inferior ao nível do coração, ocorreu uma redução da perfusão significativa, conforme verificado pelo decréscimo significativo na amplitude dos sinais de FLD e FPG entre as fases I e II $(-47.0 \%, \mathrm{p}=0.002$ e $-84.0 \%, \mathrm{p}=0.010$, respetivamente). Esta diminuição da perfusão é atribuível ao reflexo venoarteriolar (RVA), resultante da constrição arteriolar em resposta a um aumento da pressão venosa ${ }^{[16]}$ local. O sangue acumulou-se na extremidade do pé, após o seu abaixamento, por força da gravidade, provocando um aumento da pressão nestes territórios vasculares. Pensa-se que o aumento da pressão transmural venosa possa provocar uma constrição local arteriolar através de um reflexo neuro-mediado não-adrenérgico, reduzindo o fluxo sanguíneo da microcirculação local ${ }^{[17]}$. Além disso, também se acredita que o aumento da pressão transmural arterial induz um aumento do tónus miogénico que contribui igualmente para a redução da perfusão ${ }^{[18]}$. O sistema nervoso simpático também parece ter influência no RVA, em particular na posição

Table 1/ Tabela 1 - Mean and standard deviation of the measured variables for each phase of the protocol. Statistical comparison for phase I is presented $(p<0.05, N A-$ non applicable).

Média e desvio-padrão das variáveis medidas para cada fase do protocol. A comparação estatística para a fase I é apresentada ( $\mathrm{p}<0.05, \mathrm{NA}$ - não aplicável).

\begin{tabular}{ccccc}
\hline Variable / Variável & Phase I / Fase I & Phase II / Fase II & Phase III / Fase III & \% var I-II \\
\hline LDF control (AU) / FLD & $20.2 \pm 21.5$ & $13.5 \pm 12.7$ & $10.5 \pm 9.6$ & $-21.1 \pm 19.6$ \\
controlo (UA) & - & $0.004^{*}$ & $0.003^{*}$ & $\mathrm{NA}$ \\
\hline $\mathrm{LDF}$ test (AU) / FLD teste & $18.0 \pm 18.3$ & $8.2 \pm 10.1$ & $9.9 \pm 10.6$ & $-47.0 \pm 21.0$ \\
(UA) & - & $0.002^{*}$ & $0.003^{*}$ & $\mathrm{NA}$ \\
\hline $\mathrm{PPG}$ control (AU) / FPG & $154.5 \pm 120.9$ & $106.4 \pm 89.7$ & $107.7 \pm 102.0$ & $-29.7 \pm 15.8$ \\
control (UA) & - & $0.018^{*}$ & $0.003^{*}$ & $\mathrm{NA}$ \\
\hline PPG test (AU) / FPG teste & $123.6 \pm 69.5$ & $15.3 \pm 14.2$ & $62.7 \pm 29.3$ & $-84.0 \pm 15.7$ \\
(UA) & - & $0.010^{*}$ & $0.003^{*}$ & $\mathrm{NA}$ \\
\hline tcpO (mmHg) & $66.3 \pm 18.8$ & $70.3 \pm 18.7$ & $65.5 \pm 20.3$ & $6.8 \pm 7.0$ \\
& - & $0.005^{*}$ & 0.241 & $\mathrm{NA}$ \\
\hline Pulse rate (bpm) / Frequência & $60.2 \pm 8.0$ & $61.4 \pm 8.1$ & $59.2 \pm 7.6$ & $2.5 \pm 12.4$ \\
de pulso & - & 0.507 & 0.476 & $\mathrm{NA}$ \\
\hline
\end{tabular}


between phases I and II $(6.8 \%, \mathrm{p}=0.005)$ in the foot dorsum. This is probably explained by the thermally-induced vasodilation caused by the measurement probe, probably overlapping the VAR-induced vasoconstriction detected ahead ${ }^{[20]}$.

Recent studies indicate that VAR only affects the region adjacent to where the venous pressure has changed ${ }^{[16]}$. However, the regional circulation homeostasis seems to be conserved in both limbs, even after the challenge test. As it happens, we detected a significant decrease in blood flow for LDF and PPG in the control foot, although less pronounced $(-21.1 \%, p=0.004$ and $-29.7 \%$ $\mathrm{p}=0.018$, respectively). Since the control foot remained in the same position during the experiment, we might admit that a centrally-mediated reflex may be involved ${ }^{[21]}$. One should note that the initial perfusion conditions were not reestablished during the experiment. Blood flow remained significantly lower during the recovery period in relation to the stabilization period, as noted by the significant reduction of both LDF and PPG signal amplitudes between phases I and III ( $p=0.003$ and $p=0.003$ respectively for the pending foot and $p=0.003$ and $p=0.003$ respectively for the contralateral foot). In our opinion this might be explained by the volunteer's skin heat loss during experiments, evoking secondary vasoconstriction. This is a recurrent situation reported by the patients, involving some discomfort that recommends us to shorten the time involved to prevent these artifacts. These results are in line with previously published studies ${ }^{[21]}$, confirming the interest of the leg pending maneuver as a practical, useful experimental model to assess peripheral microcirculation in vivo. Furthermore, it is also demonstrated that both LDF and PPG signals change similarly in each limb in terms of magnitude, suggesting that the combined use of LDF and PPG might help to look deeper into peripheral microcirculation mechanisms.

\section{Conclusions}

These results seem to confirm the usefulness of this microcirculatory assessment model as well as the techniques and analysis methods employed. It also suggests PPG as a suitable technique, easy to use and cost effective. ortostática, com ativação mediada pelos barorrecetores ${ }^{[19]}$. No presente estudo os voluntários permaneceram em supinação, evitando assim alterações mediadas por barorreceptores (a FP não se alterou significativamente durante as alterações posturais e esta situação corrobora a nossa análise). Apesar desta redução de perfusão dos dedos dos pés verificou-se um aumento significativo na $t c \mathrm{pO}_{2}$ medido no dorso do pé entre as fases I e II $(6.8 \%, p=0.005)$. Este efeito é provavelmente explicado pela vasodilatação induzida pela sonda de medição, sobrepondo-se provavelmente à vasoconstrição induzida pelo RVA detetada adiante ${ }^{[20]}$.

Estudos recentes indicam que o RVA apenas afeta a região adjacente à zona onde a pressão venosa se altera [16]. No entanto, a homeostasia da circulação regional parece ser conservada em ambos os membros, mesmo após a realização da manobra. Como se pode verificar, detetámos uma diminuição significativa no fluxo sanguíneo quer para o FLD quer para o FPG no pé controlo, embora menos pronunciada $(-21.1 \%, \mathrm{p}=0.004 \mathrm{e}$ $-29.7 \% \mathrm{p}=0.018$, respetivamente). Uma vez que o pé de controlo permaneceu na mesma posição durante a manobra, podemos admitir que um reflexo medular possa estar envolvido ${ }^{[21]}$. Note-se ainda que as condições de perfusão iniciais não foram restabelecidas durante a manobra, o que quer dizer que o fluxo sanguíneo permaneceu significativamente mais baixo durante o período de recuperação em relação ao período de estabilização, como observado pela significativa redução de ambas as amplitudes dos sinais de FLD e FPG entre as fases I e III ( $p=0.003$ e $p=0.003$, respetivamente para o pé pendente e $\mathrm{p}=0.003$ e $\mathrm{p}=0.003$, para o pé contralateral). $\mathrm{Na}$ nossa opinião, esta situação poderá ser explicada pela perda de calor pela pele do pé dos voluntários durante a manobra, o que poderia provocar uma vasoconstrição secundária. A sensação de frio é uma queixa recorrente dos pacientes, envolvendo sempre algum desconforto, e a recomendação para encurtar o tempo envolvido nas experiencias para evitar esses artefactos.

Estes resultados estão de acordo com estudos publicados anteriormente ${ }^{[21]}$, confirmando o interesse da manobra de pendência da perna como um modelo experimental prático e útil para avaliar a microcirculação periférica in vivo. Além disso, também demonstramos que tanto os sinais de FLD quanto os de FPG se alteram de forma semelhante, em termos de amplitude, em cada membro, o que sugere que o uso combinado de FLD e FPG pode permitir um estudo mais aprofundado dos mecanismos de controle e regulação da fisiologia da microcirculação periférica. 


\section{Acknowledgements}

The authors would like to express their thanks to all volunteers and to Rita Faria and Raquel Ferreira for their collaboration and assistance.

\section{Conflict of interests}

The authors declare that there are no financial and/or personal relationships that could be viewed as presenting a potential conflict of interests.

\section{Conclusões}

Estes resultados parecem confirmar a utilidade deste modelo de avaliação da microcirculação, bem como as técnicas e métodos de análise utilizados. Também sugerem a utilização do FPG como uma técnica adequada, fácil de utilizar e de baixo custo.

\section{Agradecimentos}

Os autores gostariam de expressar seus agradecimentos a todos os voluntários, bem como à Rita Faria e à Raquel Ferreira pela sua colaboração e assistência.

\section{Conflito de interesses}

Os autores declaram não existir qualquer relação pessoal ou financeira que possa ser entendida como representando um potencial conflito de interesses. 


\section{References / Referências}

1. Holowatz LA, Thompson-Torgerson CS Kenney WL. The human cutaneous circulation as a model of generalized microvascular function. J Appl Physiol 2008; 105: 370372 .

2. Abularrage CJ, Sidawy AN, Aidinian G, Singh N, Weiswasser JM, Arora S. Evaluation of the microcirculation in vascular disease. $\mathrm{J}$ Vasc Surg 2005; 42: 574-581.

3. Rossi M, Carpi A. Skin microcirculation in peripheral arterial obliterative disease. Biomed Pharmacother 2004; 58: 427-431.

4. Rodrigues LM, Pinto PC, Fluhr JW. In vivo assessment of peripheral vascular function by $\mathrm{tcpO}_{2}$ and skin blood flow modelling. Exp Dermatol 2012; 21(1):38-42.

5. Silva H, Ferreira H, Bujan MJ, Rodrigues LM. Regarding the quantification of peripheral microcirculation--Comparing responses evoked in the in vivo human lower limb by postural changes, suprasystolic occlusion and oxygen breathing. Microvasc Res 2015 May;99:110-7

6. Silva H, Rosado C, Antunes J, Rodrigues LM. Exploring human in vivo microcirculation with methyl nicotinate in different perfusion conditions. Biomed Biopharm Res 2014; 11(2):207-214.

7. Rajan V, Varghese B, van Leeuwen TG, Steenbergen W. Review ofmethodological developments in laser Doppler flowmetry. Lasers Med Sci 2009; 24:269-283.

8. Sahni R. Noninvasive monitoring by photoplethysmography. Clin Perinatol. 2012;39(3):573-83
9. World Medical Association, 2013. World Medical Association Declaration of Helsinki: ethical principles for medical research involving human subjects. JAMA310, 21912194.

10. de Trafford J, Lafferty K. What does photoplethysmography measure? Med Biol Eng Comput 1984; 22(5):479-80.

11. Leonard PA, Douglas JG, Grubb NR, Clifton D, Addison PS, Watson JN. A fully automated algorithm for the determination of respiratory rate from the photoplethysmogram. J Clin Monit Comput 2006;20:33-6

12. Blanc VF, Haig M, Troli M, Sauve B. Computerized photoplethysmography of the finger. Can J Anaesth 1993;40:271-8

13. Shelley KH. Photoplethysmography: beyond the calculation of arterial oxygen saturation and heart rate. Anesth Analg. 2007;105(6 Suppl):S31-6.

14. Winsor T, Haumschild DJ, Winsor DW, Wang Y, Luong TN. Clinical application of laser Doppler flowmetry for measurement of cutaneous circulation in health and disease. Angiology 1987;38(10):727-36.

15. Silva H, Ferreira H, Bujan J, Monteiro Rodrigues $\mathrm{L}$. The wavelet transform as a tool for the characterization of the vascular response in the human lower limb. Biomed Biopharm Res 2014; (11) 1:75-80
16. Okazaki K, Fu Q, Martini ER, Shook R, Conner C, Zhang R, Crandall CG, Levine BD. Vasoconstriction during venous conges tion: effects of venoarteriolar response, myogenic reflexes, and hemodynamics of changing perfusion pressure. Am J Physiol Regul Integr Comp Physiol 2005;289(5):R1354-9.

17. Crandall CG, Shibasaki M, Yen TC. Evidence that the human cutaneous venoarteriolar response is not mediated by adrenergic mechanisms. J Physiol 2002; 538(Pt 2): 599-605.

18. Pedrinelli R, Dell'Omo G, Mariani M. Calcium channel blockers, postural vasoconstriction and dependent oedema in essential hypertension. J Hum Hypertens 2001;15(7):455-61.

19. Henriksen O. Local sympathetic reflex mechanism in regulation of blood flow in human subcutaneous adipose tissue. Acta Physiol Scand Suppl 450; 1-48, 1977

20. Davison JL, Short DS, Wilson TE. Effect of local heating and vasodilation on the cutaneous venoarteriolar response. Clin Auton Res. 2004; 14(6):385-90.

21. Hassan AA, Tooke JE. Mechanism of the postural vasoconstrictor response in the human foot. Clin Sci (Lond). 1988;75(4):37987. 